\title{
$O$-GIcNAc Transferase: Functions, Structure, and Development of Inhibitors
}

\author{
O-GlcNAc 転移酵素 : 機能、構造、そして、阻害剂の開発
}

Key Words: O-GlcNAc, OGT, glycosyltransferase, inhibitor

Unlike other types of glycosylation, $O$-linked $\mathrm{N}$-acetylglucosamine (GlcNAc) is attached to cytoplasmic or nuclear proteins. Given that a broad spectrum of proteins are modified with $O$-GlcNAc and implicated in diseases such as diabetes, $O$-GlcNAc transferase (OGT), which transfers $O$-GlcNAc from the nucleotide sugar UDP-GlcNAc to proteins, has been extensively studied. Here I will introduce several recent interesting papers on the unusual activity of OGT, its structure, and development of inhibitors.

Capotosti and co-workers showed that OGT not only modifies the $\mathrm{HCF}-1_{\mathrm{N}}$ subunit of the human epigenetic regulator HCF-1, but also, surprisingly, cleaves the HCF- $1_{\mathrm{PRO}^{-}}$ repeat [Capotosti, F. et al. (2011) Cell 144, 376-388]. HCF-1 is a transcriptional co-regulator conserved among animal species that was first discovered as a host-cell factor for human herpes simplex virus infection. Proteolysis occurs at six centrally located 26 -amino acid $\mathrm{HCF}-1_{\mathrm{PRO}}$-repeat sequences and results in the formation of a non-covalently associated heterodimer. HCF-1 regulates cell cycle progression in that the $\mathrm{HCF}-1_{\mathrm{N}}$-subunit promotes passage through the G1 phase while $\mathrm{HCF}-1_{\mathrm{C}}$-subunit ensures proper mitosis and cytokinesis in $\mathrm{M}$ phase. Although HCF-1 proteolytic maturation was known to be necessary for activation of human $\mathrm{HCF}-1_{\mathrm{C}^{-}}$ subunit function in $\mathrm{M}$ phase, the precise mechanism of the HCF-1 proteolysis remained to be elucidated. Using inhibitors of $O$-GlcNAc modification (OGT inhibitors such as alloxan or RNAi on OGT), they demonstrated that addition of $O$-GlcNAc was required for proteolytic cleavage. Subsequent mass spectrometric analysis showed that $O$-GlcNAc modification occurs on the HCF- $1_{\mathrm{N}}$-subunit, but not on the HCF- $1_{\mathrm{PRO}}$-repeat region. They also showed that $\mathrm{HCF}-1_{\mathrm{PRO}}$-repeat itself is the target for OGT binding and that mutation of the cleavage site of HCF- $1_{\mathrm{PRO}}$-repeat enhanced OGT binding in cells. These results suggested that OGT plays a role in $\mathrm{HCF}-1_{\mathrm{PRO}}$-repeat cleavage. Next they examined which region of OGT was responsible for the cleavage. OGT consists of two distinct regions: an $\mathrm{N}$-terminal region containing tetratricopeptide repeat (TPR) units and a multidomain catalytic region. They showed that the TPR and catalytic domains of OGT are both important for $\mathrm{HCF}-1_{\mathrm{PRO}}$-repeat cleavage and that residues involved in OGT activity are important for the cleavage, which suggests that $O$-GlcNAc modification is somehow required for the cleavage. The authors propose the two models of proteolysis in one of which OGT promotes a conformational
$O$ - 結合型 $N$ - アセチルグルコサミン $(O-G l c N A c)$ は、他の 種類の糖鎖修飾とは異なり、細胞質あるいは核に局在する夕 ンパク質に扔いて起こる。非常に多くの種類のタンパク質が この修飾を受け、中には糖尿病などの疾患との関連が示唆さ れていることから、O-GlcNAc を糖ヌクレオチド供与体である UDP-GlcNAc からタンパク質に転移する酵素 (OGT) は鋭意研 究されている。本稿では、OGTの予想もしなかった活性、構造、 そして、阻害片の開発に関する最近の報告を紹介したい。

Capotosti らは、OGT がヒトのエピジェネティック制御 因子 HCF-1 の N 末サブユニット HCF-1 $1_{\mathrm{N}}$ に O-GlcNAc を付 加するだけでなく、驚くべきことに、HCF-1 $1_{\mathrm{PRO}}$-リピートを切 断することを発見した[Capotosti, F. et al. (2011) Cell 144, 376388]。HCF-1 は、転写関連因子で、ヒトヘルペスウイルス感 染の宿主因子として最初に発見された。 HCF-1 タンパク質切 断は、その一次構造上中心に位置する 26 アミノ酸からなる 配列の 6 回繰り返し構造 $\mathrm{HCF}-1_{\mathrm{PRO}}$ リ ピートで起こり、その 結果、HCF-1 は非共有結合的に相互作用するへテロダイマー を形成する。 HCF-1 は、細胞周期の進行を制御する。すなわ ち、 $\mathrm{HCF}-1_{\mathrm{N}}$ は G1 期から S 期への進行を促進し、HCF-1 の $\mathrm{C}$ 末サブユニット HCF-1 1 は、M 期の有糸分裂と細胞質分裂 が正常に進むのを助ける。 HCF-1 のタンパク質切断に伴う 成熟は、 $\mathrm{HCF}-1_{\mathrm{C}}$ の M 期に扔ける機能に必要であることが知 られていたが、HCF-1 のタンパク質切断の詳細な分子機構は 明らかになっていなかった。著者らは、OGTを阻害するアロ キサンあるいは OGT に対する RNAi 法を用いることにより、 O-GlcNAc の付加が HCF-1 のタンパク質切断に必要であるこ とを示した。そして、質量分析によって、O-GlcNAc の付加が HCF-1 の HCF-1 $1_{\mathrm{PRO}}$ リリ゚ートではなく、HCF- $1_{\mathrm{N}}$ で起こること を示した。さらに、OGT が HCF-1 の HCF-1 PRO- $_{\text {リピートに }}$ 直接結合し、また、タンパク質切断部位に変異を入れる (切断 が起こらない) と、その結合が強まることを見いだした。これ らの結果は、OGT が HCF-1 のタンパク質切断に関与してい ることを示唆している。次に、OGT のどの部位がこの切断に 寄与しているか調べた。OGT は、2 種類の異なる構造モチー フからなる。 $\mathrm{N}$ 末端側は、テトラトライコペプチドリピート (TPR) ユニット、C 末端側は、複数のドメインからなる触媒 領域である。両者が HCF-1 のタンパク質切断に必要で、OGT の活性に関与するアミノ酸残基もまた重要であったことから、 O-GlcNAc 修飾が何らかの理由によって HCF-1 のタンパク 質切断に関与していることが示唆された。著者らは、2つの モデルを提唱しているが、そのうちの 1 つは、大腸菌 RecA 
change in the HCF- $1_{\mathrm{PRO}}$-repeat and the $O$-GlcNAc stimulates hydrolysis by analogy to $E$. coli RecA-induced autocleavage of the LexA repressor. This uncovered link between OGT and HCF-1 highlights the importance of $O$-GlcNAc modification in epigenetic regulation of cell proliferation.

Two crystal structures of human OGT were reported by Lazarus, Nam, and co-workers [Lazarus, M. B. et al. (2011) Nature 469, 564-567]. One was as a binary complex with UDP ( $2.8 \AA$ resolution) and the other as a ternary complex with UDP and a peptide substrate (a well-characterized 14-residue CKII peptide) (1.95 $\AA$ resolution). They both solved the structure of human OGT with 4.5 TPR units and the catalytic domain which was as active as full length OGT. The two crystal structures were different in that the OGT-UDP-peptide complex had a wider cleft between the TPR domain and the catalytic region than the OGT-UDP complex. The structural analysis of the OGT-UDP-peptide complex revealed not only how OGT recognized the peptide substrate, but also provided a mechanistic insights into the kinetic "ordered" mechanism in which UDP-GlcNAc binds to the nucleotide-sugar binding pocket of the OGT before the peptide substrate. Furthermore, the authors suggested that His 498 is a catalytic base in OGT since His 498 is invariant, critical for activity, and located between the hydroxyl group of the serine residue in the peptide substrate that is modified with $O$-GlcNAc and the UDP-GlcNAc binding pocket. The authors also pointed out that the most unusual feature of OGT is the intervening domain between the catalytic lobes, which adopts a topologically novel fold with a seven-stranded $\beta$-sheet core stabilized by flanking $\alpha$-helices. The intervening domain and an adjacent helix of the catalytic domain form a large basic surface comprising ten lysine residues. The function of this surface remains to be elucidated.

The Harvard group also reported the mechanism of action of a small molecule that inhibits OGT [Jiang, J. et al. (2011) Nat. Chem. Biol. 8, 72-77]. The authors identified Compound $\mathbf{1}$ containing a benzoxazoline (BZX) core in a high-throughput screen of 65,000 compounds to identify glycosyltranferase inhibitors that they had previously reported. They made several derivatives of Compound $\mathbf{1}$ using commercially available building blocks, and checked their inhibiting activities. Several derivatives showed an irreversible reduction in enzymatic activity in vitro, and the largest effect was observed for Compound $\mathbf{2}$, which contained a ketone on the BZX core and a $p$-methoxy group on the phenyl ring. Compound $\mathbf{2}$ inhibited $O$-GlcNAcylation in cells, consistent with cell permeability. Mass spectrometric analysis on Compound 2-treated OGT detected two adducts. The major adduct had a mass increase of +26 Da while the minor one had a mass increase of $+176 \mathrm{Da}$. Further analysis revealed that Compound 2 crosslinks between Lys 842 and Cys 917 of OGT.
誘導性の LexA リプレッサーの自己切断のように、OGT は $\mathrm{HCF}-1_{\mathrm{PRO}^{-}}$リピートの構造変化を誘導し、O-GlcNAc が加水分 解を促進するというモデルである。OGT と HCF-1 とのこれ まで知られていなかった関連が明らかになったことから、細 胞増殖のエピジェネティックな制御におけるO-GlcNAc の重 要性が浮かび上がってきた。

Lazarus と Nam らは、ヒト OGT の 2 種類の結晶構造を 報告した[Lazarus, M. B. et al. (2011) Nature 469, 564-567]。1つは、 UDP との二者複合体で (解像度 $2.8 \AA$ )、もう一方は、UDP と、非常に良く調べられている CK II 由来の 14 残基からなる OGT の基質ペプチドとの三者複合体である(解像度 $1.95 \AA$ )。 構造解析には、全長の OGT と同様の活性を有する、4.5 個分 の TPR ユニットと触媒領域を含むリコンビナントの OGT が 用いられた。2 種類の結晶構造は、OGT-UDP-ペプチド複合 体が TPR ユニットと触媒領域との間に、より広い空間をもつ という点で異なっていた。OGT-UDP-ペプチド複合体の構造 解析により、OGTによる基質ペプチドの認識機構だけでなく、 酵素の反応機構にも重要な示唆が得られた。すなわち、OGT への基質の結合には順序があり、先に UDP-GlcNAc が結合し、 その後、ペプチドが結合するようである。さらに、著者らは、 保存された OGT のヒスチジン 498 が、酵素活性に必要で、基 質ペプチド中の O-GlcNAc で修飾されるセリンヒドロキシル 基と UDP-GlcNAc 結合ポケットとの間に位置していることか ら、OGT の触媒塩基として機能していると提唱している。ま た、OGTに非常に特異な特徴として、触媒領域を隔てる構造 を持ち、この部分は $\alpha$-ヘリックスによって安定化された 7 つ の $\beta$ - シートをもつという、これまでに知られていなかった立 体構造を有していることが示された。この部分と近接する $\alpha$ ヘリックスとで、10 個のリジン残基を含む大きな塩基性表面 を形成しているが、このことの機能的重要性は不明である。

ハーバード大の同グループは、OGT を阻害する低分子 を同定し、その作用メカニズムを報告している [Jiang, J. et al. (2011) Nat. Chem. Biol.8, 72-77]。著者らは、以前に報告してい た糖転移酵素阻害剤のハイスループットスクリーニング法を 用いて 65,000 種の分子からベンゾキサゾリン (BZX) 核をもつ 化合物 1 を同定した。購入可能なビルディングブロックを用 いて、化合物 1 の誘導体を合成し、OGT 阻害活性を調べると、 不可逆的な活性抑制作用を in vitro で示したいくつかの誘導 体の中で、化合物 2 が最大の阻害活性を示した。化合物 2 は、 BZX 核にケトン基、フェニル環に $p$-メトキシ基を有してい た。化合物 2 は、細胞透過性をもち、実際、細胞においても O-GlcNAc 修飾を抑制した。質量分析により、化合物 2 で処 理された OGT には、2 種類の付加体が検出され、主要なもの は、26ダルトン、もう一方は、176 ダルトン、分子量が増加 したものであった。さらなる解析により、化合物 2 は、OGT のリジン 842 とシステイン 917 とを架橋していることが明ら かとなった。この結果に基づいて、著者らは、カルボニル基 
Based on the results, they proposed a double-displacement mechanism which form a carbonyl crosslink, consistent with the incorporation of the $\mathrm{C}=\mathrm{O}$ and the loss of two protons (+26 Da). The crosslink by Compound 2 was confirmed by structural analysis on the OGT treated with Compound $\mathbf{2}$ and crystallized in the presence of UDP and CKII. Computational docking analysis showed that Compound 2 contains a fiveheteroatom dicarbamate core that functions as a neutral diphosphate mimic. One dicarbamate carbonyl reacts with an essential active site lysine that anchors the diphosphate of UDP-GlcNAc.

Independently from the above work, Gloster and coworkers also developed an OGT inhibitor [Gloster, T. M. et al. (2011) Nat. Chem. Biol. 7, 174-181]. They "hijacked" the hexosamine biosynthetic pathway (HBP) in cells to produce a UDP-GlcNAc analog capable of inhibiting OGT. Their rationale was that, since glycosyltranferases use a catalytic mechanism involving a cationic transition state in which the geometry of the pyranose ring likely plays a critical role, 2-acetamido-2-deoxy-5-thio-D-glucopyranose (5SGlcNAc), which has a sulfur atom instead of an oxygen atom in the endocyclic ring of GlcNAc, would be a good candidate for a cell-permeable biosynthetic precursor. They showed that 5SGlcNAc and its per- $O$-acetylated analog, 2-acetamido-1, 3, 4, 6-tetra- $O$-acetyl-2-deoxy-5-thio- $\alpha$-D-glucopyranose (Ac5SGlcNAc) can be salvaged by cells and processed via the HBP to generate UDP-5SGlcNAc, which inhibits OGT and lowers cellular $O$-GlcNAc levels. They showed that there was no apparent interference with cell surface glycosylation or $\mathrm{N}$-glycosylation of an individual protein, IgG, by using several lectins. Given that there are several UDP-GlcNAc-transferases that work in the lumenal side of the endomembranes, it will be important to elucidate whether UDP-5SGlcNAc is transported there and inhibits them. Nonetheless, the authors rationally designed an inhibitor that behaves like a natural substrate for a nucleotide sugar donor and acts in cells for the first time.

$O$-GlcNAc modification has been a hot topic for the past decade. These papers provide new findings on OGT based on rigorous experimental results. If you read them, you will realize how the authors enthusiastically performed their experiments. Given the broad presence of $O$-GlcNAc-modified proteins that are involved in many fundamental cellular processes, the work introduced here should be appreciated by readers from many different backgrounds including Glycobiology.

\section{Reported by Hideyuki Takeuchi}

Dept. of Biochemistry and Cell Biology, Stony Brook University

Stony Brook, NY 11794-5215, USA

htakeuchi@ms.cc.sunysb.edu
の付加と 2 個のプロトンの消失を伴うカルボニル基による架 橋という二重置換モデルを提唱している。化合物 2 による架 橋は、この化合物で処理し、UDP と CKII 共存下で結晶化し た OGT の構造解析でも確認された。コンピューターによる ドッキング解析で、化合物 2 は、中性ジリン酸類似体として 機能する 5 つの異種原子からなるカルバミン酸核を有し、1 つのカルバミン酸のカルボニル基が、UDP-GlcNAc のジリン 酸との反応に必要な OGT の活性中心に存在するリジンと反応 する。

上の研究とは独立して、Gloster らも OGT を阻害する物 質を開発している [Gloster, T. M. et al. (2011) Nat. Chem. Biol. 7, 174-181]。著者らは、細胞内に㧈けるへキソサミン合成経路 (HBP) を“乗っ取る”ことで OGT を阻害することができる UDP-GlcNAc 類似体を細胞に産生させた。糖転移酵素の触媒 機構はカチオン遷移状態が関係し、ピラノース環の構造が重 要であるので、GlcNAc の環内の酸素原子を硫黄原子に置き換 えた 2-アセタミド-2-デオキシ -5-チオ -D-グルコピラノース (5SGlcNAc) が細胞透過性をもつ生合成前駆体の良い候補にな るだろうと考えた。著者らは、 $5 \mathrm{SGlcNAc}$ とそのアセチル化体 2-アセタミド-1, 3, 4, 6- テトラ -O-アセチル -2-デオキシ -5- チ オ -D-グルコピラノース (Ac-5SGlcNAc) が細胞に取り込まれ、 HBP 経路によって、UDP-5SGlcNAc へと変換され、OGT を 阻害し、細胞に抢ける O-GlcNAc 修飾を低下させることを示 した。著者らは、いくつかのレクチンを用いた実験によって、 細胞表面の糖鎖修飾、および、ここでは IgG を例として、単 一のタンパク質の $N$ - 結合型糖鎖修飾には影響がないことを 示した。OGT 以外にも細胞内小器官の管腔側で働く複数の GlcNAc 転移酵素が知られているので、UDP-5SGlcNAc が細 胞内小器官の管腔側にも運ばれ、それらの酵素をも阻害する のかという疑問は残るが、本研究で、著者らは天然に存在する 糖核酸供与体の前駆体であるかのように細胞内でふるまう物 質を論理的に初めて合成することに成功した。

O-GlcNAc 修飾はこの 10 年ホットトピックであり続けて いる。本稿で紹介した論文は厳密な実験結果に基づいて得ら れた OGTに関する新しい知見である。これらを読むと、著者 らの熱意が伝わってくる。O-GlcNAcで修飾される多くの夕ン パク質が基本的な細胞内に抄ける事象に関与することを考元 ると、これらの論文は、糖鎖生物学を含む広い範囲のバック グラウンドをもつ方々によって高く評価されるであろう。

\section{竹内 英之}

ストーニーブルック大学 